\title{
Comparative Research on Women's EMPLOYMENT
}

\author{
Tanja van der Lippe ${ }^{1}$ and Liset van Dijk ${ }^{2}$ \\ ${ }^{I}$ Department of Sociology/ICS, Utrecht University, The Netherlands; \\ e-mail: t.vanderlippe@fss.uu.nl \\ ${ }^{2}$ Nivel (Netherlands Institute for Health Services Research), The Netherlands; \\ e-mail:l.vandijk@nivel.nl
}

\begin{abstract}
Key Words institutional context, childcare arrangements, family policy, paid work, gender
\end{abstract}

- Abstract Women's employment has been widely studied in both Western countries and Eastern Europe. In this article, the most frequently used measurements and descriptions of women's paid work are given, namely, participation rate, number of hours worked, gender segregation, and the gender gap in earnings. Next, three approaches used to study women's employment are discussed: 1. the macro-level approach, which gives a thorough understanding of the influence of the institutional context on women's work; 2. the micro-level approach, which compares individual-level results in a number of countries; and 3. the macro-micro approach, in which the relative importance is shown of institutional and individual level factors. Finally, a review is given of the hypotheses and outcomes of both the institutional level, with welfare regime and family policy playing an important role, and the individual level, which shows that being a mother has an important effect on women's employment in the different countries studied.

\section{INTRODUCTION}

Women's work is a widely studied phenomenon. The increase in female labor force participation in Western countries has led to a profound interest of sociologists in the causes and effects of women's work. Although labor market patterns in Western Europe and the United States in the latter half of the twentieth century, particularly in the past 25 years, have shown a striking resemblance when it comes to the increase in women's employment, there are many contrasts as well. The comparison of Western countries regarding this topic has received much attention (Treiman \& Roos 1983, Rosenfeld \& Kalleberg 1990, Gornick et al. 1998).

East European countries differ considerably from Western countries when it comes to women's employment. High female employment rates were a rule in Eastern Europe, and differences between countries before the fall of communism seemed to be smaller than they were in the West during that period (Van Dijk 2001). 
After the political turnover in 1989, the socialist regimes began to move in the direction of capitalism, which affected women's employment in particular (Einhorn 1993, Heitlinger 1993, Funk \& Mueller 1993). Eastern Europe has therefore been a unique area for comparative research, where the effect of an actual change in the institutional context on the individual lives of men and women can be studied (Van der Lippe \& Van Dijk 2001, Rijken \& Ganzeboom 2001).

Although several indicators of women's employment have been used in comparative research, most cross-national research on women's employment has focused on labor force participation rates and on the number of hours worked (Rosenfeld \& Birkelund 1995, Blossfeld \& Hakim 1997, Van der Lippe \& Van Dijk 2001, Evans et al. 2001). Also, a number of studies have concentrated on material rewards (Treiman \& Roos 1983, Rosenfeld \& Kalleberg 1991) or on the segregation of the sexes in the workplace (Rubery et al. 1998).

Different approaches have been used to explain differences in women's employment between and within countries. These different approaches entail not only different theoretical views but also different ways of handling data. A first approach studies women's work at the macro level by comparing differences in institutional contexts (for example, Sainsbury 1994, Den Dulk 2001). Second, the micro approach explains women's employment by means of large-scale data-sets on the individual level (Trappe \& Rosenfeld 2001). Third, lately there has been a tendency to combine the macro approach and the micro approach: Aspects of women's employment are explained by individual characteristics as well as by the institutional context. One could say that, in this last approach, the usually descriptive comparative studies at the macro level and the explanatory studies based on individual-level data are combined into one analysis (Rijken \& Ganzeboom 2001, Gornick et al. 1998). Whatever approach is used, research shows that institutional factors such as the welfare regime or the availability of childcare options explain differences in women's employment, in addition to individual-level factors such as the presence of children (Van der Lippe 2001).

To summarize, the contrasts and similarities between countries make the study of women's employment in a comparative context relevant from a sociological point of view. It is important to know to what extent the institutional context influences the behavior of women and to what extent characteristics of women themselves or their immediate family situations are responsible for their behavior. The aim of this article is to give an overview of research on women's employment from a comparative perspective, its measurement and description, as well as to examine the different approaches. The review is restricted to the research of the past 25 years because in this period comparative research has risen in importance. We start with an overview of the indicators most often used in comparative research on women's employment. Next, we discuss the different ways of studying women's employment from a comparative perspective, namely, the macro-level approach, the micro-level approach, and a combination of these two. We then discuss hypotheses about women's employment and outcomes, at both the institutional and the individual level in different countries. We conclude by addressing the 
differences and similarities in institutional contexts and their effects on women's work, as well as discussing the advantages and disadvantages of the different approaches.

\section{MEASUREMENTS AND DESCRIPTION OF WOMEN'S WORK}

Women's employment can be measured in a variety of ways, and even when the same indicator is used, the precise measures differ from study to study. We describe the most frequently used indicators of women's employment in comparative research. These indicators are economic activity, number of hours worked, gender segregation, and wage differences. Although these indicators are described separately, it is good to note that they relate to and influence each other.

\section{Economic Activity Status}

An important indicator to describe and compare women's position in the labor market is economic activity status (for example Gornick et al. 1998, Rønsen \& Sundstrom 1998). In official documents, economic activity status is almost always expressed as employment or activity rate [European Commission 1996, Organisation for Economic Co-operation and Development (OECD) 1998, 2001, International Labor Office 1999]. The employment rate is the number of employed women relative to the total population of working age; the participation or activity rate is the employment rate plus the number of registered unemployed women of working age (OECD 2001). Whatever measure of economic activity status is used, it may be problematic when women's employment in different countries is described and compared, because it is not simply the question whether or not women are involved in paid work (yes or no) that matters for economic activity (Rubery et al. 1998, Greenwood 2001). In some countries women mainly do part-time work, while in other countries women usually work full-time. Furthermore, women in some counties participate in unpaid family work (other than homemaking) more often or are on leave for maternity or childcare purposes.

These differences cause difficulties in comparing countries when it comes to economic activity participation rates of women. Despite these difficulties, there are clear differences between countries. Results show that for a long time now, Nordic countries, such as Sweden and Denmark, have had higher levels of female labor force participation (76\% in 2000; OECD 2001) than other Western countries. The Anglo-Saxon countries, like the United States and the United Kingdom have been runners-up (70\% in 2000), while in Italy, Greece, and Spain, still only half of the female population participate in the labor market (European Commission 1996, International Labor Office 1975, 1985, 1995, 2000, United Nations 1999, Eurostat 2000, OECD 2001). For a long time, the Netherlands used to have a low level of women's employment, but recently the number of working women has increased at a faster rate than in most other Western countries (OECD 2001). Increases in 
Western countries have been especially dramatic for married women (Jenson et al. 1988, Drew et al. 1998), although in Southern European countries the percentage of married women who work, $37 \%$ in 1997, is still substantially lower than in Scandinavian countries and the United States, where it is 63\% (Eurostat 1998a, U.S. Census Bureau 1997).

Under the influence of the socialist regime, the female labor force participation rate in East European countries was high compared to Western countries in the 1960s; this picture remained stable until the political turnover in 1989. After the political turnover, economic activity rates have decreased in East European countries (International Labor Office 1975, 1985, 1995, 2000, United Nations 1999, OECD 2001). This decrease seems to be due to a general decrease of employment in Eastern Europe. This is suggested by the fact that, when expressed as a percentage of the male activity rate, the female activity rate has increased in most of the former socialist countries between 1988 and 1995 (United Nations' Development Program 1990, 1998). In Western countries, the corresponding figure has increased as well, but here it is caused by an increase in women's employment rather than a decrease in male economic activity.

\section{Number of Hours Worked}

Despite the overall increase in the level of women's employment in the industrialized world, there are considerable differences between countries when it comes to the number of hours women work for pay. Most research focuses on choices of women between part-time work and full-time work (Rosenfeld \& Birkelund 1995, Blossfeld \& Hakim 1997), although part-time work is thereby defined differently. The ILO definition refers to jobs of a significantly lower number of hours than the normal hours worked in that job (Hussmans et al. 1990), whereas the OECD defines part-time work in terms of usual working hours under 30 per week (OECD 2000). Hakim (1993, 1997) argues that there are three types of part-time jobs: (a) reduced hours (weekly hours a little shorter than usual), (b) half-time jobs (15-29 hours a week), and (c) marginal jobs (only a few hours a week). Both the ILO and Hakim definition leave room for different definitions of part-time work across occupations or jobs. Moreover, one can argue about the usual number of hours work in a job and about the cutpoint of part-time work.

Using Hakim's definition, working reduced hours is common in countries such as Sweden, Denmark, and Norway; working half-time is prevalent in Britain, Germany, France, and Belgium; and marginal hours are found especially in the Netherlands. In the United States, Greece, Spain, and Portugal, most women work full-time (Rosenfeld \& Birkelund 1995, Fagan \& Rubery 1996, Eurostat 1997, Blossfeld \& Hakim 1997, Hakim 1997, Plantenga \& Hansen 1999). In Eastern Europe, part-time work simply did not exist before the political turnover. Almost ten years later, full-time work is still the rule in the former socialist countries (Van der Lippe \& Fodor 1998, OECD 2001). 


\section{Gender Segregation}

The rising number of women active in the labor market has had little or no effect on occupational gender segregation (Persson \& Jonung 1998). Gender segregation is more conventionally measured by occupation than by industry. Occupational data at the international level are, however, much less widely used than industrial data, and there are considerable question marks against the comparability of such data as are available (Rubery et al. 1998). Therefore, information on gender segregation usually refers to industrial sectors (agriculture, industry, service). In virtually all countries, women are overrepresented in the service sector, whereas men are overrepresented in the industrial sector (Eurostat 1998a, Melkas \& Anker 2001). Especially in Nordic countries, the level of horizontal occupational segregation is high compared to other industrialized countries, due to the fact that a high percentage of women are active in female-dominated occupations (Melkas \& Anker 2001). In East European countries before the political turnover, there were more women active in the industrial and agricultural sectors than in Western countries, which implies that the occupational structure was less segregated (Van der Lippe $\&$ Fodor 1998). However, since the political turnover, the service sector has been growing in Eastern Europe. As in the West it is usually women who enter the service sector; as such, the occupational structure in the former socialist countries more and more resembles that of the West. In South European countries, such as Greece and Portugal, the agricultural sector is still substantial in size. The number of women working in this sector is considerably higher than in West European countries (Plantenga \& Tijdens 1995).

\section{Hourly Earnings}

With respect to hourly earnings, attention in comparative research is given to the gender gap in earnings, rather than to the absolute earnings of women (Rosenfeld \& Kalleberg 1991). Women's earnings are lower than men's throughout the world (International Labor Office 1975, 1985, 1995, 2000, Eurostat 1998b, U.S. Census Bureau 1996, Roos \& Gatta 1999). Moreover, women have less authority in the workplace than men (Wright et al. 1995). In Nordic countries, the gender gap in earnings is somewhat smaller (Melkas \& Anker 2001), and in the United States, Australia, and Canada relatively many women occupy managerial positions (UNDP 1998). In Eastern Europe, too, the gender gap in earnings was substantial during the socialist period; the same goes for the difference in authority levels (Sørensen \& Trappe 1995, Van der Lippe \& Fodor 1998).

\section{THREE APPROACHES}

The approaches used in comparative research on women's employment, regardless of which aspects are studied, are characterized by their own theoretical point of view, the explanatory factors used, their data-sources, and the way these data are 
handled (Van der Lippe \& Van Dijk 2001). Roughly, there are three approaches to studying women's employment; all use each other's insights.

\section{Macro Approach}

In comparative research on women's employment, it is often argued that the societal context plays a crucial role in women's labor market decisions. Countries differ with respect to institutions, regulations, laws, structures, and norms concerning women's work (Buchmann \& Charles 1995, Orloff 1993, 1996, Nelson 1994). When studying women's employment, it is therefore useful to specify the institutional context that systematically influences the perceptions and actions of individual women in a given period of time. In macro-level studies, the context is related to women's work at the institutional level, but the intention is not to analyze the choices individual women make (Rubery et al. 1998). One of the best known typologies used in macro level research to study all kinds of topics is the one developed by Esping-Andersen (1990, 1999), who used institutional characteristics of countries to develop a typology of Western welfare regimes. Researchers studying women's employment in different welfare regimes often use this typology (Gustafsson 1994), sometimes refined to be more gender specific (Sainsbury 1994), or discussed extensively (Gornick et al. 1997, Van Dijk 2001, Den Dulk 2001). This typology therefore deserves a short explanation.

In his study, Esping-Andersen (1990) describes the differences between three welfare regimes in terms of pension rights, employment structure, and power structure. The liberal welfare regime (United States, United Kingdom) is characterized by the important role the market plays and a strong emphasis on the sovereignty of the state. Only if the market fails does the state interfere. Benefits are means-tested and usually assigned only to low-income state dependents. In the conservative welfare regime (Italy, Ireland), the preservation of status differences dominates: rights are attached to class and social status. The breadwinner ideology is dominant, and family benefits are aimed to encourage motherhood. Only if the family cannot meet its own needs does the state subsidize it. The social-democratic welfare regime (Sweden, Denmark) is based on the idea of equal rights for all citizens. Benefits are universal and usually not means-tested; social rights are based on citizenship. The state is committed to a full-employment guarantee. The welfare state is extensive.

Feminist scholars have criticized Esping-Andersen's typology for the little attention it pays to the role of the family in welfare states and its neglect of the importance of nonpaid activities (Langan \& Ostner 1990, Siim 1991, Plantenga \& Van Doorne-Huiskes 1992, Lewis 1993, Sainsbury 1994, 1996, Bussemaker \& Van Kersbergen 1994). They argue that the extent to which the welfare state enables people to lead a life besides or outside the family, or the extent to which it allows mothers and their children to be supported without a man, has to be taken into account as well. In his latest book, Esping-Andersen (1999) acknowledges the gender critique and reexamines his typology by introducing the concept of defamilialization. De-familialization refers to the degree to which welfare state or market provisions ease the burden of caring responsibilities of families. Examining 
de-familialization by means of welfare state policies, Esping-Andersen (1999) shows that the Scandinavian countries form a distinctive cluster. Sweden, Norway, Denmark, and Finland are the only countries with extensive family policies. In both liberal and conservative regimes, family policies are residual, but for different reasons: the liberal view sees it as a market activity and an individual responsibility; conservatives insist that family policies are the prerogative of families.

One way to examine the relation between institutional factors and women's employment is to compare descriptive country reports with each other (Drew et al. 1998); this has been done for Western countries (Jenson et al. 1988) as well as East European countries (Lobodzińska 1995). These macro studies provide rich descriptions of the institutional contexts in which women work.

Another way is to correlate cross-country measures of various economic, social, and political dimensions with measures of gender differences, such as the percentage of employed women who work reduced hours (Rosenfeld \& Birkelund, 1995), the ratio of women's and men's earnings (Rosenfeld \& Kalleberg 1991), or other indicators of women's employment (Rubery et al. 1998, Van Doorne-Huiskes et al. 1995). To be able to do this, many countries have to be included in the analysis (Rosenfeld \& Kalleberg 1991, Phipps \& Burton 1995, Van Dijk 2001). The merit of this approach lies in the fact that differences in institutional contexts are studied and related to differences in the development of women's employment. However, Trappe \& Rosenfeld (2001) argue that this approach ignores differences between countries in the distribution of women and men over age groups, educational level, citizenship, ethnicity, marital status, and such. Moreover, there are obvious empirical limitations in using this approach. These studies show that it is difficult to obtain data on all kinds of institutional indicators (Van Dijk 2001), and therefore, it is hard to use the same institutional indicators when many countries are included in one analysis. The nature of public childcare, for example, can differ considerably between countries A and B. Moreover, within countries A and B the system for public childcare provision can change over time, making a comparison between the countries even more difficult, and it may be necessary to make strong assumptions in order to be able to compare countries accurately. To put it differently: The gain of including many countries in one analysis goes hand in hand with a considerable loss in depth. According to Gornick et al. (1998) this is also one of the reasons why progress in this field is limited. Another problem of using macro-level factors is how to bundle the different aspects of the national context. Using large categories such as the types of welfare regime may not capture all the relevant differences between countries, while using a large number of economic, political, and social indicators to tap more cross-country variation makes it difficult to draw any substantial conclusion (Trappe \& Rosenfeld 2001).

A possible solution to overcome the problems mentioned is to include a select group of countries in the analysis (e.g., one country per welfare regime). This enables the researcher to pay much more attention to institutional backgrounds (Den Dulk 2001). However, in that case the choice of countries is a delicate one. Usually, the countries included are regarded as representative of a group of countries with, for example, the same political system. Sweden, for instance, is often chosen as 
the prime example of a social-democratic country. As Van Dijk (2001) shows, however, countries within a regime show, next to their similarities, considerable variation on several aspects. Therefore, choosing representative countries has to be done carefully, and at least the main differences have to be discussed between the "representative" country and the countries it is supposed to represent.

\section{Micro Approach}

Much research has been conducted in which paid work is studied in either a single country over a period of time or a number of different countries at one point in time (for example, Jenson et al. 1988, Arber \& Gilbert 1992, Lewis 1993, Van DoorneHuiskes et al. 1995). Since the goal in these studies is to gain an understanding of women's considerations regarding paid employment, relatively much attention is paid to detailed information at the micro level. One can argue about the term "micro approach." We choose this term to distinguish this approach from the macro-level studies in which the focus is on the relationship between institutional arrangements and women's employment at the macro level, and from the macro-micro approach in which indicators for the institutional level are combined in one analysis with individual variables. However, often the micro approach lies in between the macro approach and the macro-micro approach.

Micro studies usually explain certain aspects of women's work, using largescale data-sets with individual-level information and multivariate techniques to unravel the mechanisms at the individual level. The countries are analyzed separately; to explain differences between countries in the effects of individual characteristics on women's work, institutional features such as a country's history, government, or social-economic structure are only described or referred to. Sometimes only a few countries are studied (Trappe \& Rosenfeld 2001, Panayotova \& Brayfield 1997), and sometimes studies include over ten countries (Treiman \& Roos 1983, Blossfeld \& Hakim 1997). Among the first cross-national statistical analyses on women's employment were those of Roos \& Treiman (Roos 1983, 1985, Treiman \& Roos 1983). Using individual-level data from 12 industrialized countries, they examined the effects of marital status, education, and occupation on women's income (Treiman \& Roos 1983). Other, more recent examples are studies on part-time work in the Western world (Blossfeld \& Hakim 1997), family life and family policy (Kaufman et al. 1997), earnings of men and women in different contexts (Rosenfeld \& Kalleberg 1990, Gornick \& Jacobs 1998, Trappe \& Rosenfeld 2001), the gender gap in workplace authority (Wright et al. 1995), and attitudes of women toward employment in Hungary and the United States (Panayotova \& Brayfield 1997). These kinds of studies represent a compromise between case studies and quantitative multi-level comparative analyses by comparing individual-level results for a number of countries, although they cannot explicitly link particular aspects of the institutional context to the results from the quantitative analyses of life histories. However, in micro-level studies that include just a few countries it is possible to provide much information on the institutional level and as such to connect this information to individual women's work position. A good example of such a study is the one by Trappe \& Rosenfeld (2001), who 
clearly explain—although they do not test—differences in women's earnings in the two former Germanies.

\section{Macro-Micro Approach}

Increasingly, research is conducted in which aspects of women's employment are explained by both individual characteristics and features of the institutional context (Gornick et al. 1998, Van der Lippe 2001, Rijken \& Ganzeboom 2001). In this approach, the usually descriptive comparative studies at the macro level and the explanatory studies of large data-sets with individual-level data are combined into one analysis. Sometimes, the institutional level is measured only as the country in which women live (Brayfield et al. 2001, Tijdens 2001). In other studies, more refined institutional variables are included, often related to family policy. For example, Gornick et al. (1998) focus on the effect that family and childcare policies have on individual employment behavior of mothers in Western countries, thereby controlling for individual-level effects. Rosenfeld et al. (1998) used this approach to see what amount of variation between countries in the gender gap in workplace authority could be explained by country-level characteristics (e.g., family policies), after family status and job characteristics had been taken into account. Another option is the study by Rijken \& Ganzeboom (2001), who investigated occupational status attainment of men and women in first jobs in market-regulated and statesocialist contexts. Individual data were used from 19 countries for the period 1900-1992. They used a pooled time-series design in order to solve the wellknown problem of degrees of freedom in comparative research: Instead of a limited number of cross-sectional contexts (societies) or historical contexts (cohorts), the comparative degrees of freedom are determined by the product of these two.

The institutional indicators in macro-micro studies usually contain rather rough information, because it is often hard to find comparable measurements of institutional indicators for all countries involved, making it hard to provide much detail about the institutional level (Van der Lippe 2001), and thus, the effect of the context on women's work cannot be studied in a detailed manner. Another practical limitation of the macro-micro-level approach concerns the individual level data. Often these do not have the same level of detail as the data used in micro-level studies. The reason for this is that macro-micro studies mostly use data sets that have been collected for different purposes by different researchers. Usually at least slight differences appear in the way the characteristics of individuals, such as educational level, income, and job status, are measured. It is inevitable that a lot of information gets lost.

\section{INSTITUTIONAL HYPOTHESES AND OUTCOMES}

The general hypothesis in macro-level explanations is that cross-national variation in family policy explains a portion of the inter-country variation in women's employment (Gornick et al. 1998). Institutional indicators in comparative research can be grouped in at least three clusters. The first cluster reflects the general 
ideological and political context. In fact, this relates to the welfare regime distinction made by Esping-Andersen. The second cluster relates to the family policies within a country, which is directly connected to the first cluster, but not necessarily the same. The third well-investigated cluster is the tax regime within a country. Although other factors, such as the overall demand for labor, are also important, we concentrate on the most frequently studied institutional indicators.

\section{The Political and Ideological Context}

Although researchers interested in gender issues have responded to EspingAndersen's lack of attention for women, they have maintained both the focus on welfare state outcomes for women and the use of clusters of similar countries in the comparative research framework (Gornick \& Jacobs 1998). These researchers hypothesize that social-democratic welfare state regimes, as compared to liberal and conservative welfare regimes, enact more policies to accommodate women's participation in the labor force and that they have a higher level of decommodification (state income provision that makes people less dependent on the labor market) as well as a larger public sector. These are all arrangements that improve conditions for women to work. Liberal regimes focus mainly on equality of rights, which implies that, in the market, similarly situated and qualified men and women should be treated as equals. However, equal rights do not necessarily lead to equal outcomes. Conservative regimes encourage mothers to stay at home, and policies are developed in this vein. Besides these three western regimes, the socialist regime can be distinguished, in which men and women are considered equal, have the same rights and duties, and are expected to work full-time (ILO 1980). Contrary to the liberal regime that also stands for equal rights of men and women, the socialist regime provides ample childcare and parental leave arrangements.

Research indicates that, in general, these distinctions among welfare regimes are reflected in women's employment (Dex \& Shaw 1986, Mahon 1998a), also when other institutional and individual factors are controlled for (Van der Lippe 2001). Employment levels are highest in socialist and social-democratic regimes, followed by liberal regimes. Conservative regimes are characterized by lower employment levels than any other regime. Within welfare regimes, however, there are differences in women's employment. For instance, while the United States and Britain are classified as liberal regimes, Dex \& Shaw (1986) found that American women were more likely to work during their childbearing years and less likely to work part-time than British women. The British government has passed equal opportunity legislation and outlawed discrimination against women, but Britain has - contrary to the United States' practice-never considered affirmative action policies. Furthermore, the hypothesis that conservative countries have low levels of women's employment is not confirmed for Portugal, a fact which can be explained by the existence of a rudimentary welfare state (Plantenga \& Van DoorneHuiskes 1992). In contrast to the conservative regime, the rudimentary welfare state does not discourage women from seeking paid employment; female employment is considered necessary and a matter of course. In other Southern European 
countries such as Italy and Greece, cultural attitudes seem to favor men's employment over women's (Plantenga \& Hansen 1999).

Results with respect to the relation of the welfare regime and the gender gap in earnings show that the gender gap is smaller in social-democratic countries (Rosenfeld \& Kalleberg 1990, 1991) than in liberal countries (Rosenfeld \& Kalleberg 1990). However, Gornick \& Jacobs (1998) find that in countries where the public sector is large (this is especially the case in social-democratic countries), the concentration of women in the public sector decreases the gender inequality in pay. When labor is highly organized (in unions) and recent political regimes have a left-wing character (such as in the Scandinavian countries), one often finds that a large public service sector has emerged, which, together with the family policies of these social-democratic countries, favors part-time work by women (Rosenfeld \& Birkelund 1995).

Related to a country's ideological context is the presence of policies aimed at improving women's position in the labor market: the opportunity policies. These policies originated in the United States and are also known as equal opportunity and affirmative action policies. They comprise legislation such as the Equal Pay Act, Title VII of the Civil Rights Act, the Age Discrimination in Employment Act, and Executive Order 11246. In the European Union, there are similar policies, but their effectiveness is limited (Rees 1998), among other reasons because many proposals must be endorsed unanimously by the European Council of Ministers (Roelofs 1995). At the national level, large differences exist in Europe with respect to equal opportunity policies. Denmark, for example, has a wide range of policies, whereas in Ireland hardly any form of policy exists regarding women's position in the workplace. Not only do countries differ when it comes to equal opportunity policies, within countries large differences can be found as well. Organizations in the public sector were the first to have attempted to improve the position of women (Remery 2001). Positive action has caught on much more slowly in the private sector, where resistance to measures such as preferential treatment has been particularly strong (De Jong \& Bock 1995). For Eastern Europe, a different picture emerges. In the socialist era, organizations, in particular those under strong party control, were encouraged to promote women to higher positions in the hierarchy. More women had formal power in Eastern Europe than in Western countries (Corrin 1994, Einhorn 1993). The rapid transformation after 1989 seems to have put an end to this given the fact that the percentage of women in managerial positions is lower these days in Eastern Europe than in, for example, the United States.

\section{Family Policy}

Most comparative research on women's employment concentrates on family policies. The hypothesis is that a family-friendly policy has a positive effect on women's employment. Indicators often used to measure family policy are the level of public childcare (Gustafsson 1994, Rosenfeld \& Birkelund 1995, Van Dijk 2001), parental leave arrangements (Rosenfeld \& Birkelund 1995, Van Dijk 2001), and other financial child-related support (Rosenfeld \& Birkelund 1995, Phipps \& Burton 
1995). However, a combination of these indicators can be found as well, sometimes coupled with a differentiation in the age groups of women's children (Gornick et al. 1998), which makes it hard to disentangle the specific effects of the different indicators.

There are significant cross-national differences in government policies aimed to positively influence women's employment decisions (Jenson et al. 1988, Gustafsson 1994, Gornick et al. 1997, Kamerman 1991, Kamerman \& Kahn 1997). In general, patterns of provision of childcare match the Esping-Andersen typology of regimes quite well (Gustafsson 1994). Finland, Denmark, and Sweden provide universal provisions for publicly supported childcare and maternity leave, whereas Australia, the United Kingdom, and the United States neither provide government paid leave nor have adopted policies that guarantee access to childcare. Since East European countries were confronted at an early stage with problems of women who had to act both as employee and caregiver, it is not strange that these countries introduced professional childcare and parental leave arrangements early (Van Dijk 2001). Although parental leave arrangements have become less generous, and the availability of childcare facilities has decreased, East European countries still have some of the best provisions for working women (Erler \& Sass 1997).

Family policies have proved to influence the employment behavior of women who have an infant (Kuysten \& Strohmeier 1997, Van der Lippe 2001) and even more so that of mothers with a preschooler (Gornick et al. 1998). Sometimes the effects of the welfare regime and the childcare system add to each other (Van der Lippe 2001), as is the case in Sweden. Sometimes, however, the welfare regime and the childcare system work in opposite directions. Norway, for instance, did not keep up with the other social-democratic countries until recently. Although in Norway, the term "motherhood" includes the notion of women as providers and nurturers, this was not accommodated by a collectivization of childcare (Leira 1992, 1994). Rather, as is the case in liberal and conservative regimes, childcare was treated as a private concern and the responsibility of individual families. In Norway, childcare policies were oriented toward the needs of the child rather than those of the working mother. So, in terms of childcare provision, Norway had adopted a liberal rather than a social-democratic approach. This might explain the relatively high number of part-time working women in Norway (Leira 1992).

High levels of women's employment are often accompanied by high levels of childcare provision, yet in the liberal regimes this is definitely not the case (Van Dijk 2001). In Britain, the formal barriers to women's labor force participation have gradually been removed, but the state has done little to facilitate women's participation in the labor force by means of providing childcare (Crompton \& Harris 1997). The availability of public childcare used to be low in the United Kingdom compared to other European countries (Phillips \& Moss 1988). Even after the British government recognized the childcare needs of working mothers, it was argued that these needs should be met by the employers rather than the state (Crompton \& Harris 1997). Generally, international studies on work-family issues focus on state regulations for realizing provisions (see for instance Deven et al. 1998, Network on Childcare 1994, 1996, OECD 1995). Only recently have policies 
of individual firms been the subject of research (Haas et al. 2000). Den Dulk (2001) shows that some employers supplement public policies and provide facilities when no public provisions are available. In fact, organizations seem to have a decisive role in the implementation of work-family arrangements. Therefore, it is necessary to complement the explanations based on the type of welfare regime with studies on the actual behavior of employers.

\section{Tax Regime}

The type of tax regime available affects the (net) income of individuals and also the percentage of women active in the labor market. In countries where husbands and wives are taxed separately, women's employment does not generally increase couples' marginal income tax rate as much as in countries (such as the United States) where a couple's earnings are jointly taxed, although the total effect depends on the specific tax structure (Gustafsson 1988, OECD 1990, O'Kelly \& Carne 1986, Sundström \& Stafford 1991, Wolff 1989). Rubery et al. (1998) argue that the breadwinner model, a clear example of a non-individual tax system, is under increasing strain across Europe, due to higher levels of female employment. In principle, non-individual systems imply a disadvantage from an equal opportunities perspective, but it remains difficult to draw specific conclusions about the effects of the various tax regimes. Not only are differences hard to establish, but research into the effect of marginal tax rates on labor supply also fails to generate unequivocal results (Plantenga \& Hansen 1999). The actual magnitude of the labor response to marginal tax rates is, after more than 20 years of analysis, still the subject of debate among scientists (OECD 1994).

Phipps \& Burton (1995) show that women in countries that employ a system of joint-income taxation exhibit no statistically significant difference in labor force participation from women in countries with a system of individual taxation. Rosenfeld \& Birkelund (1995) conclude that women's decisions to take full-time rather than part-time jobs are less sensitive to tax rates than their decision to enter the labor market (OECD 1990). Mahon (1998b) also shows that the male breadwinner taxation system in Ireland is a serious hindrance to women wishing to enter the labor market. Furthermore, due to the favorable tax provisions for childcare expenses and the payment of health insurance by employers, American women were more likely to work during their childbearing years and were much less likely to work part-time in the 1980s than British women (Dex \& Shaw 1986, Mahon 1998a). This is despite the fact that the US system bases tax rates on the combined incomes of husband and wife.

\section{INDIVIDUAL HYPOTHESES AND OUTCOMES}

Although in comparative research most interest focuses on the effects of institutional indicators, attention is paid as well to the impact of individual factors. One of the aims is to understand how much of someone's behavior can be explained by 
individual characteristics and to what extent by institutional factors. Interactions between the individual level and the institutional level are especially important. We consider the individual factors studied most often in comparative research, namely, family-related factors, human capital, and norms.

\section{Family-Related Factors}

Researchers hypothesize that women's family responsibilities can explain, at least partially, gender differences in the extent and nature of women's employment. If family life has an effect on employment, it is in the negative direction, although the magnitude of the effect differs according to the indicator of employment used, and the countries studied (Drobnič et al. 1999, Blossfeld \& Rohwer 1997).

The presence of children is the most important factor in the explanation of women's participation in paid work in Western countries (Van der Lippe 2001), although the effect of the children's presence and their ages differs considerably between countries. The effect is less strong in East European and Nordic countries, which confirms the hypothesis that in former socialist and Nordic countries the provision of public childcare enables women to work outside the home. An exception is Hungary, where the effect of having a young child is similar to that in many Western countries (Van der Lippe 2001), due to the fact that many women take advantage of the generous parental leave arrangements and so do not spend time at paid work (Van Dijk 2001).

The continuity of women's employment is markedly affected by the birth of the first child (Drew et al. 1998). Reentry into part-time work of American women who left the labor market at the birth of their child has increased over time, corresponding to developments in Northern European countries (Blossfeld 1997). American mothers also reenter full-time jobs more often (Drobnič \& Wittig 1997). Part-time work is the most important form of reemployment for German mothers (Blossfeld \& Rohwer 1997) although mostly for married mothers, whereas unmarried mothers opt for full-time jobs (Drobnič et al. 1999). Dutch women with young children also prefer part-time work over full-time work although a considerable proportion of mothers, including single mothers, with young children are full-time housewives (Van Dijk \& Siegers 1996). In France, increasingly fewer mothers leave the labor market after the birth of their first child. This development may be due to the fact that the French government has reduced obstacles to maternity for full-time working women (Blossfeld 1997). This is not the case in Britain, where women have an intermittent pattern of labor force activity over the life cycle (Drew et al. 1998).

Another indicator for family life is marriage. Results show that entry into marriage still increases the transition from full-time employment to non-employment in Germany and the United States (Drobnič et al. 1999). This conclusion is valid also for some other European countries (Blossfeld \& Hakim 1997), although, for example, in France marriage has lost its importance as a determinant of women's labor force participation (Coutrot et al. 1997). 
While family constraints are important for women's employment per sé (although the effects differ across countries), they are less important in industrialized countries for the types of jobs women get and the earnings they receive once they have entered the workforce (Rosenfeld \& Kalleberg 1990). As for family composition having an effect on women's rewards, it may be the case that even social-democratic countries do not provide enough support for combining employment and family life: Large differences in effects fail to show up between countries. However, in a comparison of a Western country with a former socialist country, differences were found: Family responsibilities, in particular bearing and rearing children, account for a large part of the gender differences in earnings in West Germany as compared to East Germany (Trappe \& Rosenfeld 2001).

\section{Human Capital}

Human capital constitutes all knowledge and skills that increase an individual's productivity in the labor market (Becker 1975), and it is assumed that women try to use their human capital stock as profitably as they can. In comparative research, education is often considered the most important form of human capital investment (Van der Lippe 2001). In all Western countries, women's increasing educational investments have stimulated their participation in the labor force (Blossfeld 1997), and a high level of education has a positive effect on number of hours worked in most Western countries (Van der Lippe 2001). Particularly for more highly qualified women, part-time jobs serve as a bridge between housekeeping and paid employment, especially in the Netherlands, West Germany, and Britain (Blossfeld 1997). In East European countries, there was hardly an effect of education on number of hours worked (Van der Lippe 2001) since the socialist regimes promoted full-time employment for everyone, irrespective of their education. After 1989, many women worked full-time regardless of their educational level.

With respect to earnings, men's higher earnings, related to their more extensive education, explain a large proportion of the gender gap in earnings in countries like Sweden, Norway, the United States, and Canada (Rosenfeld \& Kalleberg 1990). Occupational sex segregation is also important in creating the sex gap in pay (Kilbourne et al. 1994).

\section{Norms}

The ways women are socialized, as well as prevailing norms in society about working women, prove to be important determinants of female labor force participation. In studies such norms are sometimes included as explanatory variables concerning paid work, but more often they form the dependent variable (Panayotova \& Brayfield 1997, Brayfield et al. 2001). Concerning both types of studies, results nearly always conform to family policies within countries (Rønsen \& Sundström 1998). There are a few exceptions (Brayfield et al. 2001). For example, in the European Union, Denmark, Belgium, and France are thought to be least likely to view children as an obstacle to female employment because of strong state support 
for maternal employment (Gornick et al. 1997, 1998, Hantrais \& Letablier 1996), yet this turns out not to be true in popular opinion (Brayfield et al. 2001). An explanation for this could be that state policies designed to facilitate maternal employment serve to heighten public awareness of the so-called child-penalty. In addition, Denmark, Belgium, and France have relatively long traditions of generous family policies, which may have increased public expectations regarding the services needed to successfully combine employment and family responsibilities. Furthermore, Norwegian mothers have more traditional working patterns, are more traditional when it comes to cohabitation outside of marriage, and are more religious than Swedish mothers (Rønsen \& Sundström, 1998). Finally, Americans are more egalitarian in their attitude than Hungarians, despite the official Hungarian policy of gender equality, its favorable labor and childcare legislation, and higher female labor force participation rates in the past four decades (Panayotova \& Brayfield 1997). Compared with Norway and Britain, women in the Czech Republic are also more conservative in their attitudes to women's employment and family life (Crompton \& Harris 1997).

\section{CONCLUSION}

Comparative research has generated many insights into women's employment in diverse societies. In general, the institutional context is an important determinant of women's position in the labor market. Childcare arrangements prove to be especially important for women's work. Childcare arrangements are often related to the welfare regime in which women live. Social-democratic and especially (former) socialist regimes usually have better childcare provisions than do liberal and conservative regimes. This results in better labor market positions for women. Individual differences, such as the nature of the family situation, prove to be important as well for women's decisions to work. The extent to which these individual characteristics affect women's work differs between countries. In East European and, to a lesser extent, Nordic countries, the family situation has less impact than in other Western countries. Again, this finding stresses the importance of the institutional context, because in countries that have good childcare facilities and/or a regime in which women's employment is ideologically and politically encouraged, women take other decisions than their counterparts where such features are absent.

There has been much progress in the field of comparative research on women's work, especially in the last decade. Research has produced both theoretical and empirical insights into differences in the causes of women's employment decisions. The combination of institutional context factors with theories focused on the individual level proves to be promising on both the theoretical and the empirical level, as this review has shown. Eastern Europe is very interesting in this respect, since it is possible to actually study the effect of institutional changes on women's lives due to the change in the institutional context. In a theoretical sense as well, this has led to new insights into the causes of women's employment.

The rise in comparative research has been accompanied by a rather differentiated focus of researchers in the field: The particular aspect of women's employment 
studied differs, the approach used varies, as well as the number and types of countries studied. Although research has inevitably led to an increase in the knowledge about the causes of women's employment in different countries and institutional contexts, there is a drawback as well, i.e., the lack of standardization. More insight into the consequences of the institutional context for women's work can be gained by more standardized research. Some approaches seem more promising than others in this respect.

For future research, we propose the following two directions: First, to further understand the workings of the institutional context on individual work-related decisions of women, we propose to follow the approach used by Trappe \& Rosenfeld (2001) in their study on gender earnings inequality. They included individuallevel data from two countries, the FRG and GDR, and combined these data with in-depth information on institutional backgrounds. In this manner, they created a compromise between a case study approach and quantitative multi-level comparative analysis. Such an approach reveals a very detailed picture of the mechanisms that underlie women's decisions in different institutional contexts. It does not, however, test the effects. Therefore, in order to be able to test the effects of the institutional context as well as the effects of individual factors on women's labor force behavior, we propose as a second possible approach to continue with the combined macro-micro level research. The study by Gornick et al. (1998) into the effects of childcare policies on women's employment, controlling for individual-level effects, can serve as an example here. Gornick et al. include comparable data on both the institutional level and the individual level, and they use appropriate multivariate techniques to analyze these data. The interaction between institutional and individual factors will be an important focus in this kind of research. In this second type of research, the challenge lies in refining the relevant institutional indicators of both women's employment and the institutional context they live in, indicators that are based on studies of the first type. In this way, more insights will be gained into the causes of women's employment in different societies.

\section{The Annual Review of Sociology is online at http://soc.annualreviews.org}

\section{LITERATURE CITED}

Arber S, Gilbert N, eds. 1992. Women and Working Lives: Divisions and Change. New York: St. Martin's

Becker GS. 1975. Human Capital. New York: Columbia Univ. Press, for the Natl. Bur. Econ. Res. 2nd ed.

Blossfeld HP. 1997. Women's part-time employment and the family cycle: a crossnational comparison. See Blossfeld \& Hakim 1997, pp. 315-24
Blossfeld HP, Hakim C, eds. 1997. Between Equalization and Marginalization: Women Working Part-Time in Europe and the United States of America. Oxford: Oxford Univ. Press. 333 pp.

Blossfeld HP, Rohwer G. 1997. Part-time work in Germany. See Blossfeld \& Hakim 1997, pp. 164-90

Brayfield A, Jones RK, Adler MA. 2001. Harmonizing work and family in the European 
Union: public perceptions of children as an obstacle to women's employment. See Van der Lippe \& Van Dijk 2001, pp. 179-202

Buchmann MC, Charles M. 1995. Organizational and institutional factors in the process of gender stratification: comparing social arrangements in six European countries. Int. J. Sociol. 25:66-95

Bussemaker J, Van Kersbergen K. 1994. Gender and welfare states: some theoretical reflections. See Sainsbury 1994, pp. 8-25

Corrin C. 1994. Magyar Women: Hungarian Women's Lives 1960-1990. New York: St Martin's. 312 pp.

Coutrot L, Fournier I, Kieffer A, Lelièvre E. 1997. The family cycle and the growth of part-time female employment in France: boon or doom? See Blossfeld \& Hakim 1997, pp. 133-63

Crompton R, Harris F. 1997. Women's employment and gender attitudes: a comparative analysis of Britain, Norway and the Czech Republic. Act. Sociol. 40:183-202

De Jong A, Bock B. 1995. Positive action in organizations within the European Union. See Van Doorne-Huiskes et al. 1995, pp. 182-202

Den Dulk L. 2001. Work-family arrangements in organizations: an international comparison. See Van der Lippe \& Van Dijk 2001, pp. 59-84

Deven F, Inglis S, Moss P, Petrie P. 1998. State of the Art Review on the Reconciliation of Work and Family Life for Men and Women and the Quality of Care Services. Res. Rep. RR44. Norwich: Dep. Educ. Employ.

Dex S, Shaw L. 1986. British and American Women at Work. London: MacMillan

Drew E, Emerek R, Mahon E, eds. 1998. Women's Work and the Family in Europe. London: Routledge. 230 pp.

Drobnič S, Blossfeld HP, Rohwer G. 1999. Dynamics of women's employment patterns over the family life course: a comparison of the United States and Germany. J. Marriage Fam. 61:133-46

Drobnič S, Wittig I. 1997. Part-time work in the United States of America. See Blossfeld \& Hakim 1997, pp. 289-314
Einhorn B. 1993. Cinderella Goes to Market: Citizenship, Gender and Women's Movements in East Central Europe. London/New York: Verso. 280 pp.

Erler GA, Sass J. 1997. Family policy measures - the parents' view. In Families with Small Children in Eastern and Western Europe, ed. U Bjönberg, J Sass, pp. 13-48. Aldershot: Ashgate

Esping-Andersen G. 1990. The Three Worlds of Welfare Capitalism. Princeton, NJ: Princeton Univ. Press. 248 pp.

Esping-Andersen G. 1999. Social Foundations of Postindustrial Economies. Oxford, UK: Oxford Univ. Press. 207 pp.

European Commission. 1996. Employment in Europe, 1996. Luxembourg: Off. Official Publ. Eur. Commun.

Eurostat. 1997. Eurostat Yearbook '97: A Statistical Eye on Europe 1986-1996. Luxembourg: Off. Official Publ. Eur. Commun.

Eurostat. 1998a. Labour Force Survey-Results 1997. Luxembourg: Off. Official Publ. Eur. Commun.

Eurostat. 1998b. Social Portrait of Europe 1998. Luxembourg: Off. Official Publ. Eur. Commun.

Eurostat. 2000. Eurostat Yearbook: A Statistical Eye on Europe. Luxembourg: Off. Official Publ. Eur. Commun.

Evans JM, Lippoldt DC, Marianna P. 2001. Trends in Working Hours in OECD Countries. Labour Market and Social Policy. Occas. pap. no. 45. Paris: OECD. 36 pp.

Fagan C, Rubery J. 1996. The salience of parttime divide in the European Union. Eur. Sociol. Rev. 12:227-50

Funk N, Mueller M, eds. 1993. Gender Politics and Post Communism: Reflections from Eastern Europe and the Former Soviet Union. New York: Routledge. 349 pp.

Gornick JC, Jacobs JA. 1998. Gender, the welfare state, and public employment: a comparative study of seven industrialized countries. Am. Sociol. Rev. 63:688710

Gornick JC, Meyers MK, Ross KE. 1997. Supporting the employment of mothers: policy 
variations across fourteen welfare states. $J$. Eur. Soc. Policy 7:45-70

Gornick JC, Meyers MK, Ross KE. 1998. Public policies and the employment of mothers: a cross-national study. Soc. Sci. Q. 79:35-54

Greenwood AM. 2001. Gender issues in labour statistics. See Loutfi 2001, pp. 69-84

Gustafsson S. 1988. Income Taxes and Women's Economic Dependency: A Comparison of West Germany and Sweden. Stockholm: Arbetslivcentrum

Gustafsson S. 1994. Childcare and types of welfare states. See Sainsbury 1994, pp. 45-61

Haas LL, Hwang P, Russell G, eds. 2000. Organizational Change and Gender Equity: International Perspectives on Mothers and Fathers at the Workplace. Thousand Oaks, CA: Sage, 291 pp.

Hakim C. 1993. Segregated and integrated occupations: a new approach to analysing social change. Eur. Sociol. Rev. 9:289-314

Hakim C. 1997. A sociological perspective on part-time work. See Blossfeld \& Hakim 1997, pp. 22-70

Hantrais L, Letablier MT. 1996. Families and Family Policy in Europe. New York: Longman

Heitlinger A. 1993. The impact of the transition from communism on the status of women in the Czech and Slovak Republics. See Funk \& Mueller 1993, 95-108

Hussmans R, Merhan F, Verma V. 1990. Labor Force, Employment, Unemployment and Underemployment: An ILO Manual on Concepts and Methods. Geneva: ILO

International Labour Office. 1975, 1985, 1995, 1999, 2000. Yearbook of Labour Statistics. Geneva: ILO

International Labour Organisation. 1980. Work and Family Life. The Role of the Social Infrastructure in Eastern European Countries. Geneva: ILO

Jenson J, Hagen E, Reddy C, eds. 1988. Feminization of the Labour Force. Padstow: Polity. 295 pp.

Kamerman SB. 1991. Child care policies and programs: an international overview. J. Soc. Issues 47:179-86
Kamerman SB, Kahn AJ, eds. 1997. Family Change and Family Policies in Great Britain, Canada, New Zealand and the United States of America. Oxford: Clarendon. 463 pp.

Kaufman FX, Kuysten A, Schulze HJ, Strohmeier KP, eds. 1997. Family Life and Family Policies in Europe, Vol 1. Oxford: Clarendon. 423 pp.

Kilbourne BS, England P, Farkas G, Beron K, Weir D. 1994. Returns to skill compensating differentials and gender bias: effects of occupational characteristics on the wages of white women and men. Am. J. Sociol. 100:689719

Kuysten A, Strohmeier KP. 1997. Ten countries in Europe: an overview. See Kaufman et al. 1997, 394-423

Langan M, Ostner I. 1990. Gender and Welfare, Towards a Comparative Framework. Pap. pres. Social Policy Assoc. Conf. Bath, UK

Leira A. 1992. Welfare States and Working Mothers. Oslo: Inst. Soc. Res.

Leira A. 1994. Combining work and family: working mothers in Scandinavia and the EC. In A New Europe: Economic Restructuring and Social Exclusion, ed. P Brown, R Crompton. London: UCL Press

Lewis J. 1993. Women and Social Policies in Europe: Work, Family and the State. Hants, UK: Edward Elgar

Lobodzińska B, ed. 1995. Family, Women, and Employment in Central Eastern Europe. Westport, CT: Greenwood. 315 pp.

Loutfi MF. 2001. Women, Gender and Work. Geneva: ILO. 565 pp.

Mahon E. 1998a. Changing gender roles, state, work and family lives. See Drew et al. 1998, pp. $153-58$

Mahon E. 1998b. Class, mothers and equal opportunities to work. See Drew et al. 1998, pp. 182-90

Melkas H, Anker R. 2001. Occupational segregation by sex in Nordic countries: an empirical investigation. See Loutfi 2001, pp.189-213

Nelson JA. 1994. Alternative perspectives on distribution within marriage. Am. Econ. Rev. 84:126-31 
Network on Childcare. 1994. Leave Arrangements for Workers with Children. A Review of Leave Arrangements in the Member States of the European Union and Austria, Finland, Norway and Sweden. Brussels: Eur. Comm. Network on Childcare and Other Measures to Reconcile Employment and Family Responsibilities

Network on Childcare. 1996. A Review of Services for Young Children in the European Union, 1990-1995. Brussels: Eur. Comm. Network on Childcare and Other Measures to Reconcile Employment and Family Responsibilities

OECD. 1990. Employment Outlook. Paris: OECD

OECD. 1994. The OECD Jobs Study: Taxation, Employment and Unemployment. Paris: OECD

OECD. 1995. Employment Outlook. Paris: OECD

OECD. 1998. Employment Outlook. Paris: OECD

OECD. 2000. Employment Outlook. Paris: OECD

OECD. 2001. Employment Outlook. Paris: OECD

O'Kelly CG, Carney LS. 1986. Women and Men in Society: Cross-Cultural Perspectives on Gender Stratification. Belmont, CA: Wadsworth. 2nd ed.

Orloff A. 1993. Gender and the social rights of citizenship: the comparative analysis of gender relations and welfare states. Am. J. Sociol. 58:303-28

Orloff A. 1996. Gender in the welfare state. Annu. Rev. Sociol. 22:51-78

Panayotova E, Brayfield A. 1997. National context and gender ideology: attitudes towards women's employment in Hungary and the United Sates. Gender Soc. 11:627-55

Persson I, Jonung C, eds. 1998. Women's Work and Wages. London: Routledge. 256 pp.

Phillips A, Moss P. 1988. Who Cares for Europe's Children? Brussels: EC

Phipps SA, Burton PS. 1995. Social/institutional variables and behavior within households: an empirical test using the Luxem- bourg income study. Fem. Econ. 1:15174

Plantenga J, Hansen J. 1999. Assessing equal opportunities in the European Union. Int. Lab. Rev. 138:351-79

Plantenga J, Tijdens K. 1995. Segregation in the European Union: developments in the 1980s. See Van Doorne-Huiskes et al. 1995, pp. $15-30$

Plantenga J, Van Doorne-Huiskes J. 1992 . Gender, Citizenship and Welfare: An European Perspective. Pap. pres. first Eur. Conf. Sociol., Vienna

Rees T. 1998. Mainstreaming Equality in the European Union. London: Routledge. $260 \mathrm{pp}$.

Remery C. 2001. Organizations, equal opportunity policies, and the position of women: the case of the Netherlands. See Van der Lippe \& Van Dijk 2001, pp. 85-105

Rijken S, Ganzeboom HBG. 2001. Women and men in state-socialist and market-regulated societies: gender differences in ascription and achievement in the first job. See Van der Lippe \& Van Dijk 2001, pp. 24563

Roelofs E. 1995. The European equal opportunity policy. See Van Doorne-Huiskes et al. 1995, pp. 122-43

Rønsen M, Sundström M. 1998. The choice between full-time and part-time work for Norwegian and Swedish mothers. See Persson \& Jonung 1998, 159-177

Roos PA. 1983. Marriage and women's occupational attainment in crosscultural perspective. Am. Sociol. Rev. 48:852-64

Roos PA. 1985. Gender and Work: a Comparative Analysis of Industrial Societies. Albany: State Univ. New York Press

Roos PA, Gatta ML. 1999. The gender gap in earnings: trends, explanations, and prospects. In Handbook of Gender and Work, ed. GN Powell, pp. 95-123. Thousand Oaks: Sage. $651 \mathrm{pp}$.

Rosenfeld RA, Birkelund GE. 1995. Women's part-time work: a cross-national comparison. Eur. Sociol. Rev. 11:111-34

Rosenfeld RA, Kalleberg AL. 1990. A 
cross-national comparison of the gender gap in income. Am. J. Sociol. 96:69-106

Rosenfeld RA, Kalleberg AL. 1991. Gender inequality in the labor market: a cross-national perspective. Act. Sociol. 34:207-25

Rosenfeld RA, Van Buren M, Kalleberg AL. 1998. Gender differences in supervisory authority: variation among advanced industrialized democracies. Soc. Sci. Res. 27:23-49

Rubery J, Smith M, Fagan C, Grimshaw D. 1998. Women and European Employment. London: Routledge. 351 pp.

Sainsbury D, ed. 1994. Gendering Welfare States. Thousand Oaks, CA: Sage. 228 pp.

Sainsbury D. 1996. Gender, Equality, and Welfare States. Cambridge, UK: Cambridge Univ. Press

Siim B. 1991. Welfare state, gender politics and equality policies: women's citizenship in the Scandinavian welfare states. In Equality Politics and Gender, ed. E Meekan, S Sevenhuijsen. London: Sage

Sørensen A, Trappe H. 1995. Frauen under Männer: Gleichberechtigung-Geleichsellung-Gleichheit? [Women and men: equal rights, equal opportunities, and equality?]. In Kollektiv und Eigensinn. Lebensverläufe in der DDR und danach, ed. J Huinink, KU Mayer, pp. 189-222. Berlin: Akademie Verlag

Sundström M, Stafford FP. 1991. Female Labor Force Participation, Fertility, and Public Policy. Stockholm Res. Rep. in Demography No. 63, Stockholm. Stockholm Univ., Demografiska avdelningen.

Tijdens KG. 2001. Are secondary part-time jobs marginalized jobs? Job characteristics of women employed less than 20 hours a week in the European Union. See Van der Lippe \& Van Dijk 2001, pp. 203-19

Trappe H, Rosenfeld RA. 2001. How do children matter? A comparison of gender earnings inequality for young adults in the former East Germany and the former West Germany. See Van der Lippe \& Van Dijk 2001, pp. 109-50

Treiman DJ, Roos PA. 1983. Sex and earnings in industrial society. Am. J. Sociol. 89:612-50
United Nations. 1999. Economic Survey of Europe 1999, $n r$ 1. New York/Geneva: United Nations

UN Development Program. 1990. Human Development Report 1990. New York/Oxford: Oxford Univ. Press

UN Development Program. 1998. Human Development Report 1998. New York/Oxford: Oxford Univ. Press

US Census Bureau. 1996. Current Population Survey. Basic Monthly Survey, Employment and Annual Average 1996. Washington, DC: US Census Bur.

US Census Bureau 1997. Current Population Survey. 1997. March Suppl. Data. Washington, DC: US Census Bur.

Van der Lippe T. 2001. The effect of individual and institutional constraints on hours of paid work of women: an international comparison. See Van der Lippe \& Van Dijk 2001, pp. 221-43

Van der Lippe T, Fodor E. 1998. Changes in gender inequality in six Eastern European countries. Acta Sociol. 41:131-49

Van der Lippe T, Van Dijk L, eds. 2001. Women's Employment in a Comparative Perspective. New York: Aldine de Gruyter

Van Doorne-Huiskes J, Van Hoof J, Roelofs E, eds. 1995. Women in the European Labour Markets. London: Paul Chapman. 258 pp.

Van Dijk L. 2001. Macro changes in public childcare provision, parental leave and women's employment: an international comparison. See Van der Lippe \& Van Dijk 2001, pp. $37-58$

Van Dijk L, Siegers JJ. 1996. The division of child care among mothers, fathers, and nonparental care providers in Dutch two-parent families. J. Marriage Fam. 58:1018-28

Wolff K. 1989. International Comparison of Married Women's Labour Force Participation: A Cross-Country Analysis for Employees in Seven Countries. Luxembourg Income Study, Work. pap. No. 48

Wright EO, Baxter J, Birkelund GE. 1995. The gender gap in workplace authority: a crossnational study. Am. Sociol. Rev. 60:407-35 


\section{CONTENTS}

Frontispiece-Stanley Lieberson

\section{Prefatory Chapter}

Barking Up the Wrong Branch: Scientific Alternatives to the Current Model of Sociological Science, Stanley Lieberson and Freda B. Lynn

\section{Theory and Methods}

From Factors to Actors: Computational Sociology and Agent-Based Modeling, Michael W. Macy and Robert Willer

Mathematics in Sociology, Christofer R. Edling

Global Ethnography, Zsuzsa Gille and Seán Ó Riain

Integrating Models of Diffusion of Innovations: A Conceptual Framework, Barbara Wejnert

Assessing "Neighborhood Effects": Social Processes and New Directions in Research, Robert J. Sampson, Jeffrey D. Morenoff, and Thomas Gannon-Rowley

The Changing Faces of Methodological Individualism, Lars Udehn

\section{Social Processes}

Violence in Social Life, Mary R. Jackman

\section{Institutions AND Culture}

Welfare Reform: How Do We Measure Success? Daniel T. Lichter and Rukamalie Jayakody

The Study of Islamic Culture and Politics: An Overview and Assessment, Mansoor Moaddel

\section{Political and Economic Sociology}

Financial Markets, Money, and Banking, Lisa A. Keister

Comparative Research on Women's Employment, Tanja van der Lippe and Liset van Dijk

\section{Differentiation and Stratification}


The Study of Boundaries in the Social Sciences, Michèle Lamont and Virág Molnár

Race, Gender, and Authority in the Workplace: Theory and

Research, Ryan A. Smith

509

\section{INDIVIDUAL AND SOCIETY}

Reconsidering the Effects of Sibling Configuration: Recent Advances and Challenges, Lala Carr Steelman, Brian Powell, Regina Werum, and Scott Carter

Ethnic Boundaries and Identity in Plural Societies, Jimy M. Sanders

Policy

Ideas, Politics, and Public Policy, John L. Campbell

New Economics of Sociological Criminology, Bill McCarthy

\section{Historical Sociology}

The Sociology of Intellectuals, Charles Kurzman and Lynn Owens

\section{INDEXES}

Subject Index

Cumulative Index of Contributing Authors, Volumes 19-28 565

Cumulative Index of Chapter Titles, Volumes 19-28

\section{ERRATA}

An online log of corrections to Annual Review of Sociology chapters (if any, 1997 to the present) may be found at http://soc.annualreviews.org/ 